\title{
The Geochemical Characteristics of Coals from the Junggar Basin in Northwest China and the Relation of the Configuration of Pristane with Maturity in Highly Mature and Over-Mature Samples
}

\author{
Yingqin $\mathrm{Wu}^{1,2 *}$, Yanqing $\mathrm{Xia}^{1 *}$, Yongli Wang ${ }^{1 *}$, Tianzhu Lei ${ }^{1}$, Yan Liu ${ }^{1}$, Yanhong Liu ${ }^{1}$, \\ Xiaohuan Hou ${ }^{1}$ and Youxiao Wang ${ }^{1}$ \\ ${ }^{1}$ Key Laboratory of Petroleum Resources, Gansu Province/Key Laboratory of Petroleum Resources Research, Institute of Geology and Geophysics, \\ Chinese Academy of Sciences, Lanzhou 730000 - PR China \\ ${ }^{2}$ Key Laboratory of Tectonics and Petroleum Resources (China University of Geosciences), Ministry of Education, Wuhan 430074 - China \\ e-mail: wuyingqin001@163.com - yqxia@|zb.ac.cn -wyll6800@|zb.ac.cn \\ * Corresponding authors
}

\begin{abstract}
Coal samples analyzed from Junggar Basin are characterized by high Total Organic Carbon (TOC) contents (63.7-82.2\%) in all samples, except the highly over-mature samples Ha-01 and $\mathrm{Ha}-02$, and high $\mathrm{S}_{2}(60.5-83.0 \mathrm{mg} \mathrm{HC} / \mathrm{g}$ rock) and Hydrogen Index (HI) values (77-118 $\mathrm{mg} \mathrm{HC/g}$ TOC), indicating the coal rocks have excellent source rock potential. The $T_{\max }$ values $\left(418-531^{\circ} \mathrm{C}\right)$, $C_{29}$ sterane $20 S /(20 S+20 R)$ ratios $(0.20-0.54)$ and $C_{31}$ homohopane $22 S /(22 S+22 R)$ ratios $(0.26-0.61)$ indicate an immature to highly over-mature stage of organic matter, which is supported by the organic geochemical maturation parameters. In addition, n-alkane carbon numbers range from $C_{11}$ to $C_{33}$ with maxima at $n-C_{19}$ or $n-C_{23}$, exhibiting unimodal distribution patterns except Ai-13 and Ha-01, and low Pr/Ph ratios (0.29-0.80) in Ai-01, Ai-13, Ha-O1 and Ha-02, indicating a suboxic reductive environment. In Wu-8, Wei-09 and Shinan-20, the Pr/Ph ratios are clearly greater than 1.0 (2.43-3.23), indicating oxic depositional conditions.

Furthermore, pristane isomers were identified in extracts from these coal samples. Using coals of different maturity, which correspond to vitrinite reflectances $\left(\% R_{o}\right)$ of $0.36-2.99 \%$, the Pristane Isomerization Ratio $(P I R)(P I R=[6(R) 10(R)+6(S) 10(S)] / 6(R) 10(S))$ ranges from 0.42 to 0.97 for the coal extracts. The value of the PIR, which is a molecular maturity parameter, is evaluated by analyzing a series of samples using known values of the molecular maturity parameter based on the sterane and hopane isomerization indices, and the Methyl Phenanthrene Index (MPI). Changes to the PIR in highly mature Ai-13 $\left(R_{o}>1.5 \%\right)$ and over-mature Ha-O1 and Ha-02 $\left(R_{o}>2.0 \%\right)$ are clear; thus, a linear correlation is evident between the PIR and $R_{o}$. The results suggest that the PIR is an appropriate indicator of maturity for the highly mature and over-mature coal samples in the Junggar Basin.
\end{abstract}

Résumé - Les caractéristiques géochimiques des charbons du Bassin de Junggar au Nord-Ouest de la Chine et la relation entre la configuration du pristane avec la maturité dans des échantillons hautement matures ou post-matures - Des échantillons de charbon analysés du Bassin de Junggar se caractérisent par une forte teneur en carbone organique total (TOC) $(63,7-82,2 \%)$ dans tous les échantillons, 
excepté les échantillons nettement post-matures Ha-01 et Ha-02 : des valeurs de $\mathrm{S}_{2}$ (60,5$83,0 \mathrm{mg} \mathrm{HC} / \mathrm{g}$ roche) et d'indices d'hydrogène (HI, 77-118 mg HC/g TOC) élevées, indiquent que les roches de charbon présentent un excellent potentiel de roche mère. Les valeurs des températures $\mathrm{T}_{\max }\left(418-531{ }^{\circ} \mathrm{C}\right)$, les rapports de stérane $\mathrm{C}_{29} 20 \mathrm{~S} /(20 \mathrm{~S}+20 \mathrm{R})(0,20-0,54)$ et les rapports d'homohopane $\mathrm{C}_{31} 22 \mathrm{~S} /(22 \mathrm{~S}+22 \mathrm{R})(0,26-0,61)$ indiquent une phase immature à forte post-maturité de matière organique, qui est étayée par les paramètres de maturation géochimique organique. En outre, les indices de carbone des $n$-alcanes sont compris entre $\mathrm{C}_{11}$ à $\mathrm{C}_{33}$ avec des maximums à $n-\mathrm{C}_{19}$ ou $n$ - $\mathrm{C}_{23}$, présentant des modèles de distribution unimodaux, excepté pour les échantillons Ai-13 19 et Ha-01, et pour les faibles rapports $\mathrm{Pr} / \mathrm{Ph}(0,29-0,80)$ dans les échantillons $\mathrm{Ai}-01$, Ai-13, Ha-01 et Ha-02, indiquant un environnement réductif suboxique. Dans les échantillons Wu-8, Wei-09 et Shinan-20, les rapports $\mathrm{Pr} / \mathrm{Ph}$ sont clairement supérieurs à 1,0 (2,43-3,23), indiquant des conditions de dépôt oxiques. En outre, des isomères de pristane ont été identifiés dans des extraits de ces échantillons de charbon. En utilisant des charbons de différentes maturités, qui correspondent aux réflectances de la vitrinite $\left(\% \mathrm{R}_{\mathrm{o}}\right)$ de 0,36-2,99\%, le PIR [rapport d'isomérisation de pristane $=[6(\mathrm{R}) 10(\mathrm{R})+6(\mathrm{~S}) 10(\mathrm{~S})] / 6(\mathrm{R}) 10(\mathrm{~S})]$ est compris entre 0,42 et 0,97 pour les extraits de charbon. La valeur du PIR, qui est un paramètre de la maturité moléculaire, est évaluée en analysant une série d'échantillons, en utilisant des valeurs connues du paramètre de maturité moléculaire basées sur les indices d'isomérisation de stérane et d'hopane, et l'indice de méthyl-phénanthrène (MPI). Des changements du PIR dans de l'Ai-13 hautement mature $\left(\mathrm{R}_{\mathrm{o}}>1,5 \%\right)$ et de l'Ha-01 et de l'Ha-02 surmature $\left(\mathrm{R}_{\mathrm{o}}>2,0 \%\right)$ sont clairs : donc, une corrélation linéaire est évidente entre le PIR et le $R_{\mathrm{o}}$. Les résultats suggèrent que le PIR est un indicateur approprié de maturité pour les échantillons de charbon hautement matures et surmatures dans le Bassin de Junggar.

\section{INTRODUCTION}

Molecular maturity parameters are useful geochemical parameters employed widely since the recognition of systematic changes in biomarker composition associated with an increase in depth and thermal maturation in natural burial sequences [1-3]. The sterane and terpane isomerization ratios $\left(\mathrm{C}_{29}\right.$ steranes $20 \mathrm{~S} /(20 \mathrm{~S}+20 \mathrm{R}), \mathrm{C}_{31}$ homohopanes $\left.22 \mathrm{~S} /(22 \mathrm{~S}+22 \mathrm{R}), T_{s} / T_{m}\right)$ and Methyl Phenanthrene Index (MPI) have been broadly applied to assess thermal maturity in crude oils and their source rocks $[1,4,5]$. Most of these maturity parameters are mainly based on the relative abundances of two stereoisomers with a relative increase in the more thermally stable, non-biological isomer compared with the isomer that exhibits the original biological inherited stereochemistry. These parameters include the absolute concentrations of steranes and homohopanes, which decrease gradually with increasing maturity, the ratio of tricyclic terpanes/(tricyclic terpanes + homohopanes), and the ratio of $T_{s} / T_{m}$, which increases rapidly at high maturities [1]. However, it was proposed that the ratios of tricyclic terpanes/(tricyclic terpanes + homohopanes) and $T_{s} / T_{m}$ could be used to investigate maturities (vitrinite reflectance values, $\% R_{\mathrm{o}}$ ) up to $1.3-1.4 \%$ [4]. Normally, maturity parameters, which are based on biomarkers, cannot be applied to highly mature oils and source rocks (with corresponding vitrinite reflectances $\left.\left(R_{\mathrm{O}}\right)>1.5 \%\right)$ or to over-mature oils and source rocks $\left(R_{\mathrm{o}}>2.0 \%\right)$. This is due to the fact that either the biomarkers are at their equilibrium values or the compounds employed in the parameters are thermally destroyed at the highly mature and over-mature stages. Therefore, the maturity of samples cannot be assessed using these parameters. Various high maturity parameters have been described and employed with great success in the last two decades (aromatic hydrocarbons, Methyl Diamantane Index (MDI)) [1, 2, 6-9]. However, most maturity parameters lack sensitivity in the highly mature area; thus, samples with similar maturity parameters cannot be distinguished. In addition, several classical aromatic hydrocarbon-based parameters show a reversal during higher levels of thermal maturity. One example is the Methyl Phenanthrene Index (MPI-1) [6], which may not be adequate when comparing oils with high maturity condensates. The MDI can only be used to measure the maturity of source rocks at highly mature stages in the vitrinite reflectance range of $0.9-2.0 \% R_{\mathrm{o}}$. As a result, the MDI cannot be used as a maturity parameter for overmature gas source rocks at a $R_{\mathrm{o}}$ greater than $2.0 \%$ [2].

Acyclic isoprenoids are widely utilized biomarkers in organic geochemistry. Studies of the lipid components of archaea continue to broaden the known range of acyclic isoprenoid skeletons in organisms, and many biomarkers of acyclic isoprenoids have been identified in sediments, crude oils and coals. In particular, regular head-to-tail linked isoprenoids are compounds which appear to be uniquely synthesized by archaea [10]. The isoprenoid hydrocarbons pristane (2,6,10,14-tetramethylpentadecane) and phytane (2,6,10,14-tetramethylhexadecane) are typical acyclic isoprenoids and have been widely assumed to be diagenetic 


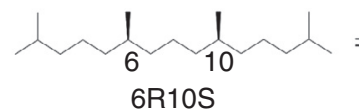

a)

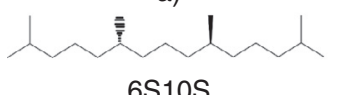

c)

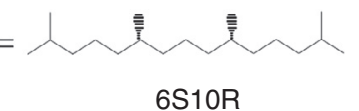

b)

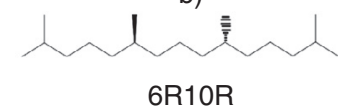

d)
Figure 1

Molecular structures of pristane isomers.

products of the phytyl side chain of chlorophyll $[4,11]$, although alternative sources of precursors have been suggested. The ratio of these two compounds is usually interpreted to be an indicator of the oxicity of the environment of deposition [12]. In addition, pristane is thought to derive from the degradation of $\alpha$-tocopherol in anoxic sediments and contains 2 chiral centers (at C-6 and C-10) and can, therefore, exist as 3 possible isomers [13]. In this case, the $6 \mathrm{R}, 10 \mathrm{~S}$ isomer (Fig. 1a,b) is separable from the unresolved enantiomers (Fig. 1c,d).

Previous studies have shown that with an increase in burial depth and increase in temperature (maturation), isomerization may occur at chiral centers. For pristane, there is a loss of stereospecificity, resulting in a mixture of the three isomers (Fig. 1a-c) at a ratio of 2:1:1 [14, 15]. In a number of cases, the structures of the geolipids were related to the enzymatically controlled stereospecificity of the presumed preceding natural products. For example, the pristane in the relatively immature Green River and Messel shales is primarily the 6(R), 10(S) (meso) compound [14].

The detailed stereochemistry of acyclic isoprenoid alkanes was studied in a suite of coal samples, ranging from lignite, sub-bituminous coal and bituminous coal to anthracite, in the Junggar Basin using GC-MS. To ensure that all of the changes observed would occur as far as possible from maturational differences, seven samples were chosen from different areas and were sorted to have different maturities. The samples reflect a wide range of burial history with a maximum vitrinite reflectance maturity assessment of $0.36-2.99 \% R_{\mathrm{o}}$. The aim of this study is to illustrate the suitability of the PIR as a parameter for high-maturity shales.

\section{GEOLOGICAL SETTING}

The Junggar Basin, located in the northern part of Xinjiang province, Northwest China, is a typical late Paleozoic, Mesozoic and Cenozoic superimposed basin (MesozoicCenozoic terrestrial sedimentary basin) with an area of approximately $1.3 \times 10^{5} \mathrm{~km}^{2}$ and also famous for its energy resources including oil, gas, coal and shale [16, 17]. The basin underwent pre-Carboniferous folding and basement metamorphism [18, 19]. From the Devonian to the Carboniferous, the basin is a platform basin in the Xingmeng Ocean surrounded by deep troughs $[18,20]$. Later during the Late Carboniferous, the basin transformed from an open marine basin into a closed continental basin [18, 20]. After that, from the Permian to the Quaternary, the basin mainly experienced three tectonic stages: a foreland basin (Permian), an intracontinental depression (Triassic-Paleogene) and a rejuvenated foreland basin (Neogene-Quaternary) [21].

The northwestern margin of the basin lies at the junction of the western Junggar Hercynian Fold Belt [22]. The coal resources are rich in the southern margin of the Junggar Basin, fulfilling the strategic goal of coal exploration. Several coal fields have been discovered primarily in the fault zone area (Fig. 2), which includes 100-meter-thick high-quality coal seams and oil shales. The coal rocks in the study area include the middle Jurassic system $\left(\mathrm{J}_{2}\right)$ and lower Carboniferous system $\left(\mathrm{C}_{1}\right)[17,23]$, and the middle Jurassic Xishanyao Formation $\left(\mathrm{J}_{2} \mathrm{X}\right)$ is the main coal-bearing stratum, with many workable coal seams in the Xishanyao Formation [23].

\section{MATERIALS AND METHODS}

The samples used in this study were collected from the seven coal mines within the Junggar Basin (Fig. 2, Tab. 1) including more immature coal ( $\mathrm{Wu}-8, R_{\mathrm{o}}=0.36 \%$ ), early mature coal (Wei-9, $R_{\mathrm{o}}=0.60 \%$ ), late mature coal (Shinan-20, $R_{\mathrm{O}}=0.80 \%$ ), late to past-oil-window coal (Ai-01, $R_{\mathrm{o}}=1.25 \%$ ), past mature coal (Ai-13, $R_{\mathrm{o}}=1.53 \%$ ), and over-mature coals (Ha-01, $R_{\mathrm{o}}=2.32 \%$ and Ha-02, $\left.R_{\mathrm{O}}=2.99 \%\right)$. The samples are rich in vitrinite (70.0$98.6 \%$ ), as is common for humic coal (Tab. 1).

About twenty grams of coal sample were broken into pieces; the broken samples were ultrasonically extracted $(3 \times)$ with dichloromethane/methanol $(93: 7, \mathrm{v} / \mathrm{v})$ for $30 \mathrm{~min}$ at $35^{\circ} \mathrm{C}$, with centrifugation after each extraction. The supernatants were combined and carefully evaporated to dryness under a steady stream of $\mathrm{N}_{2}$ at $35^{\circ} \mathrm{C}$, redissolved in a small amount of $n$-hexane/methanol (99:1, v/v) and separated into saturate, aromatic and polar fractions using column chromatography, with a mixture of pre-activated silica gel/alumina $(4: 1, \mathrm{v} / \mathrm{v})$ as a stationary phase and with $n$-hexane, dichloromethane and methanol as eluents, respectively. The fractions obtained were analyzed using the full scan and Selected Ion Monitoring (SIM) modes.

GC-MS analysis was performed using a HewlettPackard 6890 Gas Chromatograph (GC) coupled to a Hewlett-Packard 5973 Mass Selective Detector (MSD). The GC was fitted with a HP-5 capillary column 


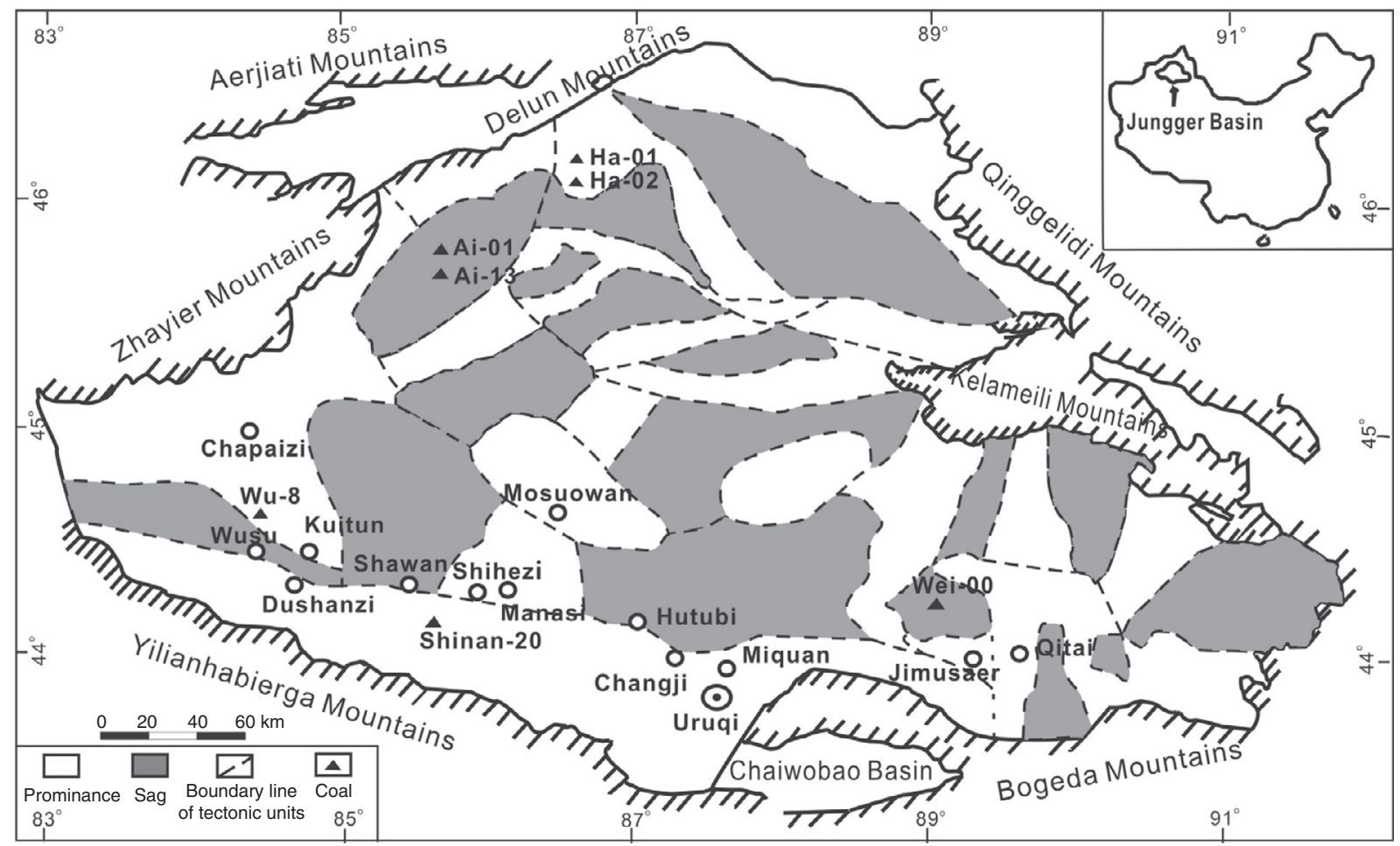

Figure 2

Locations of the five wells in the Junggar Basin from which coal samples were collected for this study.

TABLE 1

Vitrinite reflectance characteristics of the coal samples

\begin{tabular}{c|c|c|c|c|c|c}
\hline \multirow{2}{*}{ Sample } & \multirow{2}{*}{ Age } & \multirow{2}{*}{$\begin{array}{c}\text { Relative } \\
\text { maturity }\end{array}$} & \multicolumn{3}{|c|}{$\begin{array}{c}\text { Maceral composition } \\
\text { (\%) }\end{array}$} & \multirow{2}{*}{$\begin{array}{c}R_{\mathrm{o}} \\
(\%)\end{array}$} \\
\cline { 4 - 6 } & & Vitrinite & Liptinite & Inertinite & \\
\hline Wu-8 & $\mathrm{J}_{2} \mathrm{X}$ & Immature & 79.0 & 0.43 & 20.6 & 0.36 \\
\hline Wei-09 & $\mathrm{J}_{2} \mathrm{X}$ & $\begin{array}{c}\text { Early } \\
\text { mature }\end{array}$ & 83.2 & 0.60 & 16.1 & 0.60 \\
\hline $\begin{array}{c}\text { Shinan- } \\
20\end{array}$ & $\mathrm{~J}_{2} \mathrm{X}$ & $\begin{array}{c}\text { Late } \\
\text { mature }\end{array}$ & 82.1 & 0.98 & 17.0 & 0.80 \\
\hline Ai-01 & $\mathrm{J}_{2} \mathrm{X}$ & $\begin{array}{c}\text { Late to } \\
\text { past mature }\end{array}$ & 98.6 & 1.25 & 0.13 & 1.25 \\
\hline Ai-13 & $\mathrm{J}_{2} \mathrm{X}$ & Past mature & 97.2 & 1.53 & 1.26 & 1.53 \\
\hline Ha-01 & $\mathrm{C}_{1}$ & $\begin{array}{c}\text { Over- } \\
\text { mature }\end{array}$ & 86.3 & 2.40 & 11.3 & 2.32 \\
\hline Ha-02 & $\mathrm{C}_{1}$ & $\begin{array}{c}\text { Over- } \\
\text { mature }\end{array}$ & 70.0 & 2.00 & 28.0 & 2.99 \\
\hline
\end{tabular}

$(100 \mathrm{~m} \times 0.32 \mathrm{~mm} \times 0.25 \mu \mathrm{m}$, Agilent, USA). Helium was used as the carrier gas at $0.9 \mathrm{~mL} \mathrm{~min}^{-1}$. The following oven temperature program was applied: the oven temperature was raised from 80 to $280^{\circ} \mathrm{C}$ (held for $30 \mathrm{~min}$ ) at $3^{\circ} \mathrm{C} / \mathrm{min}$ for the full scan of samples (Fig. 3). In addition, an initial temperature of $80^{\circ} \mathrm{C}$ for $1 \mathrm{~min}$, an increase in temperature to $100^{\circ} \mathrm{C}$ at a rate of $3^{\circ} \mathrm{C} \mathrm{min} \mathrm{min}^{-1}$, an increase in temperature to $130^{\circ} \mathrm{C}$ at a rate of $0.3^{\circ} \mathrm{C} \mathrm{min}^{-1}$, an increase in temperature to $280^{\circ} \mathrm{C}$ at a rate of $3^{\circ} \mathrm{C} \mathrm{min}^{-1}$ and holding at this temperature for $30 \mathrm{~min}$ for the separation of pristane was carried out (Fig. 4). The injection port was set at $280^{\circ} \mathrm{C}$. The interface, ion source and quadrupole temperature were maintained at $280^{\circ} \mathrm{C}, 230^{\circ} \mathrm{C}$ and $150^{\circ} \mathrm{C}$, respectively. The ionization was carried out in an electron impact mode at $70 \mathrm{eV}$, and the data were acquired using both the full scan and SIM modes. All enantiomeric separations were confirmed with GC-MS fragmentation comparisons with the NIST library. Regular steranes were examined with $m / z 217$ fragmentograms. Terpanes, primarily consisting of homohopanes, were examined with $\mathrm{m} / \mathrm{z} 191$ fragmentograms. Acyclic isoprenoid alkanes and methyl phenanthrene were examined using $\mathrm{m} / \mathrm{z}$ 85, 123, 169, 183 and 192 mass chromatograms (Fig. 4). Nor-pristane, pristane and phytane were examined and quantified on $\mathrm{m} / \mathrm{z} 254$, 268 and 282 fragmentograms, respectively. Assignments for these compounds are given in Figure 5. Identification of the isomerization of acyclic isoprenoids in these samples is either based on comparisons with the results of Peters et al. [4] or on the examinations of the mass spectra of those compounds. 

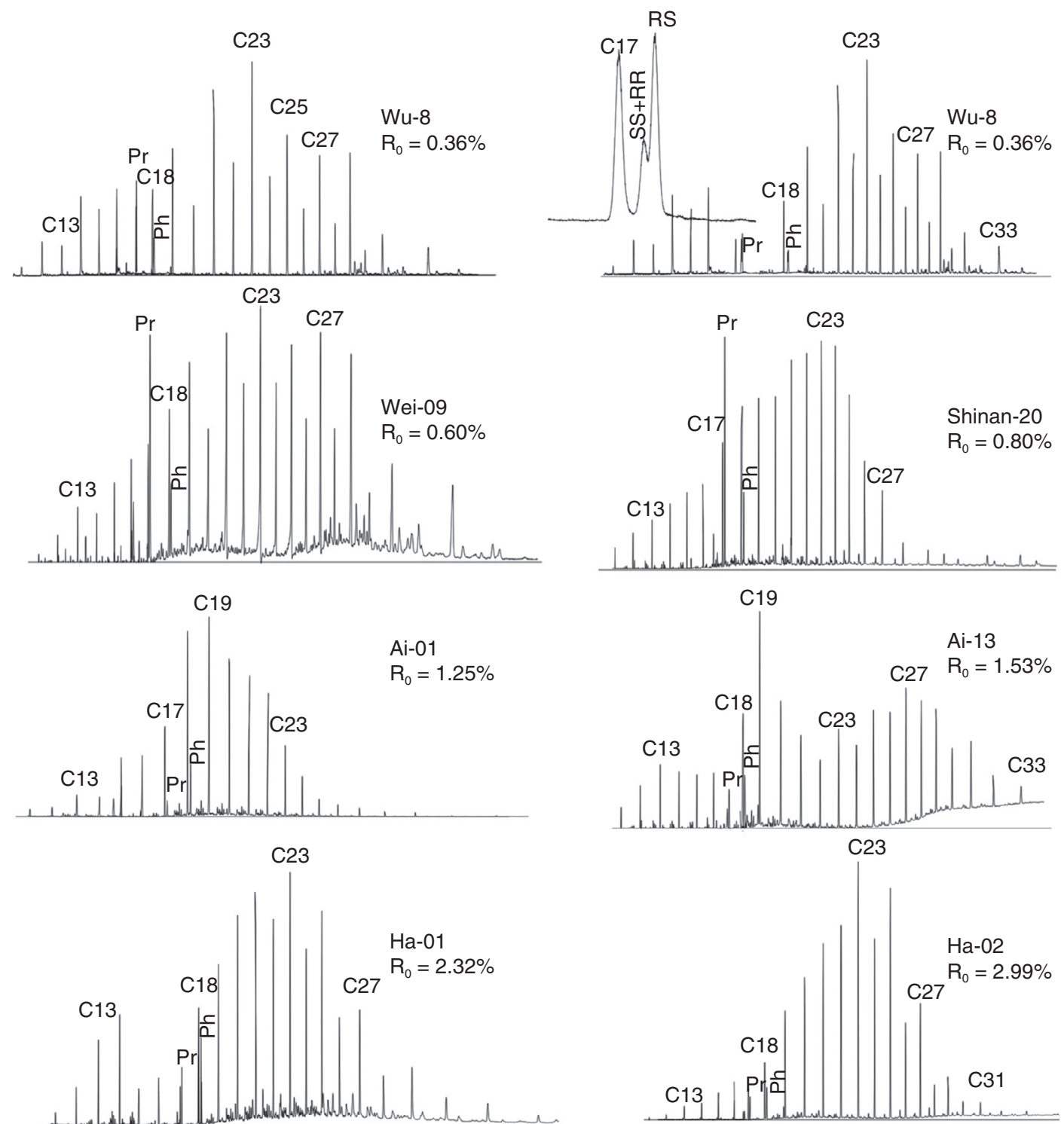

Figure 3

Representative chromatogram of $n$-alkanes and isoprenoids $(\mathrm{Pr}=$ pristane, $\mathrm{Ph}=$ phytane $)$ of the seven coals.

Component ratios for the isoprenoid alkanes were calculated from GC peak areas using the appropriate standards.

Vitrinite is a coal maceral derived from the lignin and cellulose of plant cell walls and fillings. Vitrinite reflectance $\left(\% R_{\mathrm{o}}\right)$ is a measurement of the percentage of reflected light at high $\left(500^{\circ} \mathrm{C}\right)$ magnification in oil immersion. Vitrinite reflectance increases with the increasing thermal maturity of the sample. The mounted sample plugs were polished and analyzed for $R_{\mathrm{o}}$ using a Leitz MVP III microscopic photometer system $[11,24]$.

Total Organic Carbon (TOC) contents for the samples were measured with a LECO CS-334 elemental analyzer. Prior to analysis, the samples were dried, powdered and leached with $12 \% \mathrm{HCl}$ to remove the inorganic carbon and washed with distilled water to neutral $\mathrm{pH}$, followed by drying at low temperature. All TOC values were reported in percent relative to the dry weight of the sample.

\section{RESULTS}

\subsection{Vitrinite Reflectance and Rock-Eval Pyrolysis Generation Characteristics}

The vitrinite reflectance $\left(\% R_{\mathrm{o}}\right)$ and Rock-Eval and TOC data are summarized in Tables 1 and 2. The vitrinite reflectance 


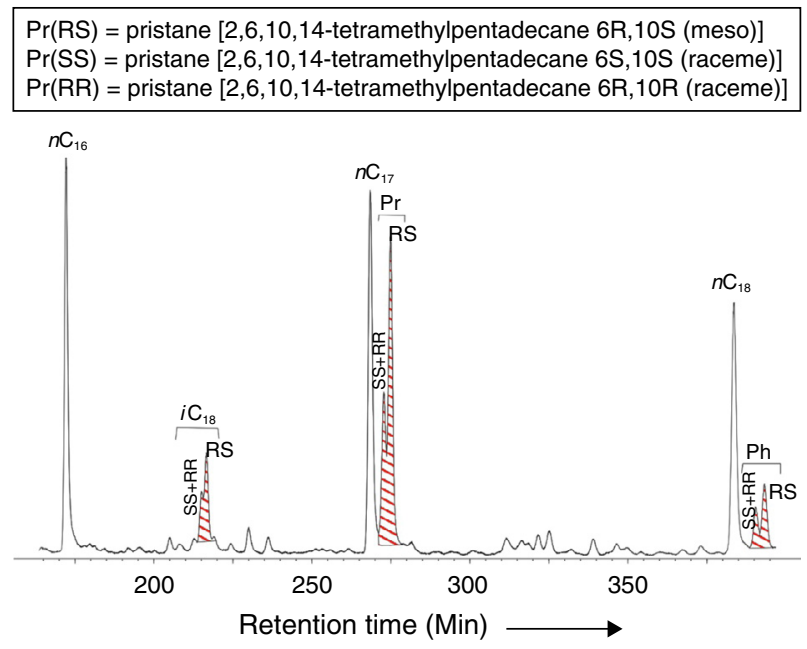

Figure 4

Baseline separation between acyclic isoprenoid isomers. Partial $\mathrm{m} / \mathrm{z} 85$ mass chromatograms of nor-pristane, pristane and phytane fractions of a coal.

and Rock-Eval pyrolysis are used to determine the hydrocarbon potential, thermal maturity of the organic matter and its ability to generate oil and/or gas [11]. The pyrolysis gives rise to the parameters $S_{1}, S_{2}$, Potential Yield (PY), the Hydrogen Index (HI), the Oxygen Index (OI) and $T_{\max }$. The vitrinite reflectance $\left(\% R_{\mathrm{o}}\right)$ ranges between 0.36 and 2.99 with a big change interval (Tab. 1). The $T_{\max }$ values range from 418 to $531^{\circ} \mathrm{C}$ (Tab. 2). These results are consistent with the low maturity to high over-maturity of the organic matter in the study area. The TOC in the samples are high, from 63.70 to $82.20 \%$; the average value is $74.31 \%$ (Tab. 2). The average $S_{1}, S_{2}$ and PY values are $2.83,71.72$ and $73.83 \mathrm{mg} \mathrm{HC} / \mathrm{g}$ coal rock for samples, with the exception of samples Ha-01 and Ha-02, which were $0.63,4.00$ and $4.63 \mathrm{mg} / \mathrm{g}$ coal rocks, respectively (Tab. 2). The HI values are from 77 to $118 \mathrm{mg} \mathrm{HC/g}$ TOC in Wu-8, Wei-09, Ai-01 and Ai-13, indicating the coals have a very high hydrocarbon generation potential [11]. However, in Ha-01 and Ha-02, the HI values are 7 and $2 \mathrm{mg} \mathrm{HC/g} \mathrm{TOC,}$ respectively (Tab. 2). The OI value differs widely from 2 to $78 \mathrm{mg} \mathrm{CO}_{2} / \mathrm{g} \mathrm{TOC}$, and it gradually decreases with the increase in the maturity of coal.

\subsection{Molecular Composition}

As illustrated in Figure 3, the gas chromatograms of the aliphatic fractions are characterized by the presence of abundant $n$-alkanes as well as pristane (Pr) and phytane $(\mathrm{Ph})$.
$n$-Alkanes are in the $\mathrm{C}_{11}$ to $\mathrm{C}_{33}$ range, with peaks of $n$ - $\mathrm{C}_{19}$ or $n-\mathrm{C}_{23}$ (Fig. 3); except for Ai-13 and Ha-01, the coal rocks studied show a unimodal distribution. The OEP is significantly greater than 1.0 for Wu-8, Wei-09 and Shinan-20 (Tab. 3), indicating that odd-numbered $n$-alkanes are dominant in these samples. However, it is nearly 1.0 for Ai-01, $\mathrm{Ai}-13$, Ha-01 and $\mathrm{Ha}-02$, indicating that odd-numbered $n$-alkanes are not dominant in these samples. In $\mathrm{Wu}-8$, Wei-09 and Shinan-20, the Pr content is higher than the Ph content, and the $\mathrm{Pr} / \mathrm{Ph}$ ratios range from 2.43 to 3.23 . The $\mathrm{Pr} / \mathrm{Ph}$ ratios are clearly greater than 1.0 , indicating oxic depositional conditions. However, in Ai-13, Ha-01 and $\mathrm{Ha}-02$, the $\mathrm{Ph}$ content is higher than the Pr content, and the $\mathrm{Pr} / \mathrm{Ph}$ ratios range from 0.73 to 0.80 (Fig. 3, Tab. 3). This shows a suboxic reductive environment [4]. In Ai-01, the ratio of $\mathrm{Pr} / \mathrm{Ph}$ is 0.28 . This is thought to be due to reduction environments [4]. The difference in $\mathrm{Pr} / \mathrm{Ph}$ values here may also be caused by the impact of maturity to a certain degree [25].

\subsection{Separation of Pristane using GC-MS}

The $\mathrm{C}_{19}$ alkane 2,6,10,14-tetramethylpentadecane has been clearly identified in a series of coals from the Junggar Basin. The process of determining the relative configuration of pristane in geological samples has been discussed [15], in which the meso (I, II) isomer is separated from the two enantiomers (III, IV). The samples (Wu-8 and Wei-09) showed a preference in favor of the meso isomer (Fig. 6). Although the absolute configuration has not been examined, all of the samples appear to show some degree of isomerization. The relative abundance of the III and IV enantiomers (SS + RR) in all of the samples shows a trend of increasing isomerization (Fig. 6), yet Ha-02 shows a nearly complete isomerization. With previous geochemical investigations, stable hydrocarbons increase in relative abundance over less stable ones with an increase in thermal stress. Therefore, we assume that the acyclic isoprenoids can be used in maturity assessment for highly mature coals and oils.

\section{DISCUSSION}

\subsection{Depositional Environment}

The $n$-alkanes are in the $\mathrm{C}_{11}-\mathrm{C}_{33}$ range, and the relative abundance from $n-\mathrm{C}_{17}$ to $n-\mathrm{C}_{27}$ of the low-carbon-numbered $n$-alkanes is presented in Figure 3. Such a distribution is thought to be characteristic of herbaceous input to these coal rocks [26]. A strong odd-even carbon predominance also exists between $\mathrm{C}_{17}$ and $\mathrm{C}_{31}$ (Wu-8 and Wei-09), as is found with land plant $n$-alkanes [27]. However, Shinan-20 and Ai-01 show no odd-even carbon predominance. They may be derived primarily from the membrane lipids of 

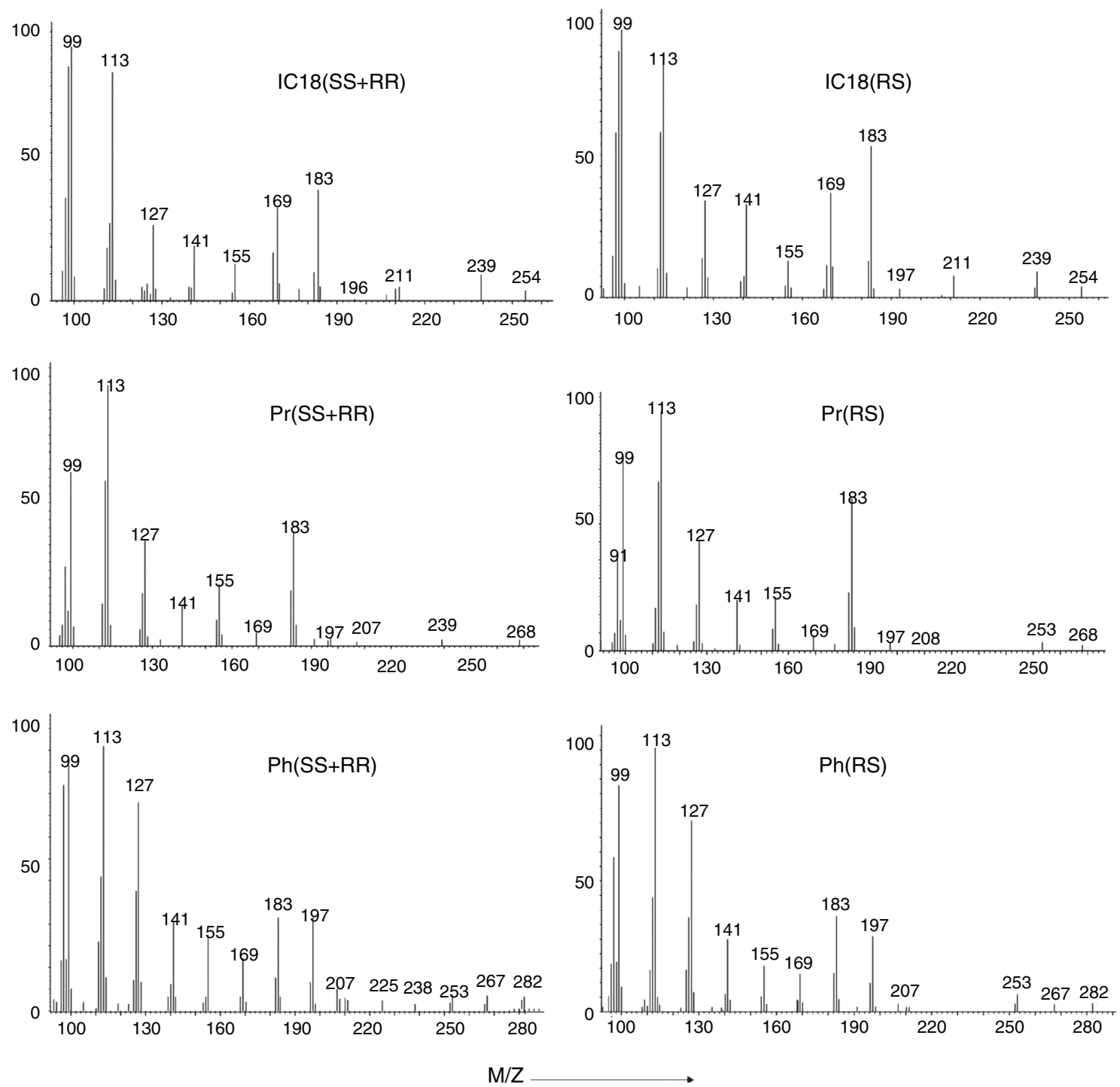

Figure 5

Full scan mass spectra of nor-pristane, pristane and phytane isomers.

microorganisms or by microbial reworking of plant $n$-alkanes [26]. The pristane is formed from the chlorophyll phytyl side chain by an oxidative pathway, while phytane is generated through various reductive pathways; the ratio of pristane to phytane $(\mathrm{Pr} / \mathrm{Ph})$ has been proposed as an indicator of the oxicity of the depositional environment [28, 29]. As shown in Table 3, the ratio of $\mathrm{Pr} / \mathrm{Ph}$ is within the range of 0.29 to 0.80 for Ai-01, Ai-13, Ha-01 and Ha-02. These values are thought to be due to a reduction to weak oxidation-reduction environment, which is possibly favorable for reducing conditions in the lacustrine sediments. However, in Wu-8, Wei-09 and Shinan-20, a $\mathrm{Pr} / \mathrm{Ph}>3.0$ typifies terrigenous organic matter input under oxic conditions $[4,30]$. The $\mathrm{Pr} / n-\mathrm{C}_{17}$ and $\mathrm{Ph} / n-\mathrm{C}_{18}$ values are smaller than 1.0 in the coal rocks of Ai-01 and Ha-02; this suggests that the microbial activity was weak. In other coal rocks the $\mathrm{Ph} / n-\mathrm{C}_{18}$ values are smaller than 1.0; however, the $\operatorname{Pr} / n-\mathrm{C}_{17}$ values are greater than 1.0 , which would indicate that there was microbial activity, but not too strong [4].

\subsection{Maturity of the Organic Matter}

The kerogen maturity was evaluated on the basis of RockEval $T_{\max }$. The range of $T_{\max }$ values varies between 418 and $531^{\circ} \mathrm{C}$ (Tab. 2). This range indicates that the thermal maturity level of the organic matter belongs to the immature to highly over-mature [4]. The ratios of $\mathrm{C}_{29}$ steranes $20 \mathrm{~S} /$ (20S+20R), $\mathrm{C}_{29}$ steranes $\beta \beta /(\beta \beta+\alpha \alpha)$ and $\mathrm{C}_{31}$ homohopanes 
TABLE 2

Results of Rock-Eval/TOC analysis and calculated parameters

\begin{tabular}{|c|c|c|c|c|c|c|c|}
\hline Sample & $T_{\max }\left({ }^{\circ} \mathrm{C}\right)$ & $S_{1}(\mathrm{mgHC} / \mathrm{g})$ & $S_{2}(\mathrm{mgHC} / \mathrm{g})$ & $\mathrm{PY}\left(S_{1}+S_{2}\right)$ & TOC (\%) & $\begin{array}{c}\mathrm{HI} \\
(\mathrm{mgHC} / \mathrm{gTOC})\end{array}$ & $\begin{array}{c}\mathrm{OI} \\
\left(\mathrm{mgCO}_{2} / \mathrm{g} \text { TOC }\right)\end{array}$ \\
\hline Wu-8 & 418 & 2.15 & 75.2 & 77.35 & 63.70 & 118 & 78 \\
\hline Wei-09 & 435 & 1.95 & 60.50 & 62.45 & 73.30 & 82 & 11 \\
\hline Shinan-20 & 431 & 1.25 & 72.90 & 74.15 & 69.70 & 104 & 14 \\
\hline $\mathrm{Ai}-01$ & 463 & 5.30 & 83.00 & 88.30 & 77.2 & 107 & 7 \\
\hline $\mathrm{Ai}-13$ & 479 & 3.50 & 63.50 & 67.00 & 82.20 & 77 & 6 \\
\hline На-01 & 531 & 0.70 & 6.25 & 6.95 & 79.40 & 7 & 3 \\
\hline Ha-02 & 530 & 0.55 & 1.75 & 2.30 & 74.70 & 2 & 2 \\
\hline
\end{tabular}

TOC = Total Organic Carbon; $S_{1}=$ free hydrocarbons; $S_{2}=$ pyrolyzable hydrocarbons; PY = Potential Yield; HI = Hydrogen Index; OI = Oxygen Index; $T_{\max }=$ temperature of maximum $S_{2}$.

TABLE 3

Geochemical parameters of the coals studied in the Junggar Basin

\begin{tabular}{|c|c|c|c|c|c|c|c|c|c|c|c|}
\hline \multirow{2}{*}{ Sample } & \multirow{2}{*}{ OEP } & \multicolumn{3}{|c|}{ Isoprenoids } & \multirow{2}{*}{$\begin{array}{c}\mathrm{C}_{29} \alpha \alpha 20 \mathrm{~S} / \\
(20 \mathrm{R}+20 \mathrm{~S})\end{array}$} & \multirow{2}{*}{$\begin{array}{l}\mathrm{C}_{29} \beta \beta / \\
(\alpha \alpha+\beta \beta)\end{array}$} & \multirow{2}{*}{ MPI-1 } & \multirow{2}{*}{ MPI-2 } & \multirow{2}{*}{$\begin{array}{c}\mathrm{C}_{31} \alpha \beta 22 \mathrm{~S} / \\
(22 \mathrm{R}+22 \mathrm{~S})\end{array}$} & \multirow{2}{*}{ PIR } & \multirow{2}{*}{$R_{\mathrm{o}}(\%)$} \\
\hline & & $\mathrm{Pr} / \mathrm{Ph}$ & $\operatorname{Pr} / n-\mathrm{C}_{17}$ & $\mathrm{Ph} / n-\mathrm{C}_{18}$ & & & & & & & \\
\hline Wu-8 & 2.45 & 2.43 & 1.42 & 0.44 & 0.20 & 0.21 & 0.25 & 0.38 & 0.26 & 0.42 & 0.36 \\
\hline Wei-09 & 1.90 & 2.66 & 1.81 & 0.52 & 0.30 & 0.24 & 0.42 & 0.50 & 0.39 & 0.67 & 0.60 \\
\hline Shinan-20 & 1.19 & 3.23 & 1.83 & 0.47 & 0.45 & 0.33 & 0.57 & 0.64 & 0.45 & 0.74 & 0.80 \\
\hline $\mathrm{Ai}-01$ & 1.12 & 0.29 & 0.16 & 0.26 & 0.51 & 0.43 & 1.13 & 1.30 & 0.58 & 0.81 & 1.25 \\
\hline $\mathrm{Ai}-13$ & 1.09 & 0.80 & 2.67 & 0.48 & 0.54 & 0.38 & 1.76 & 2.11 & 0.60 & 0.84 & 1.53 \\
\hline На-01 & 1.01 & 0.75 & 1.58 & 0.72 & 0.51 & 0.44 & 0.73 & 0.85 & 0.61 & 0.90 & 2.32 \\
\hline Ha-02 & 1.07 & 0.73 & 0.79 & 0.52 & 0.53 & 0.41 & 0.31 & 0.49 & 0.59 & 0.97 & 2.99 \\
\hline
\end{tabular}

$\mathrm{OEP}=\left(\mathrm{C}_{23}+6 \mathrm{C}_{25}+\mathrm{C}_{27}\right) / 4\left(\mathrm{C}_{24}+\mathrm{C}_{26}\right) ; \mathrm{Pr} / \mathrm{Ph}=$ pristane/phytane; MPI-1 = $1.5 \times(2 \mathrm{MP}+3 \mathrm{MP}) /(\mathrm{P}+1 \mathrm{MP}+9 \mathrm{MP}) ; \mathrm{MPI}-2=(3 \times 2 \mathrm{MP}) /(\mathrm{P}+1 \mathrm{MP}+9 \mathrm{MP}) ;$

$\mathrm{PIR}=2,6,10,14$-tetramethylpentadecane $[6(\mathrm{R}) 10(\mathrm{R})+6(\mathrm{~S}) 10(\mathrm{~S})] / 6(\mathrm{R}) 10(\mathrm{~S})$;

$\mathrm{C}_{29} \alpha \alpha 20 \mathrm{~S} /(20 \mathrm{R}+20 \mathrm{~S})=\mathrm{C}_{29}-5 \alpha(\mathrm{H}), 14 \alpha(\mathrm{H}), 17 \alpha(\mathrm{H}), 24$-ethylcholestane $20 \mathrm{~S} /(20 \mathrm{~S}+20 \mathrm{R})$;

$\mathrm{C}_{29} \beta \beta /(\alpha \alpha+\beta \beta)=\mathrm{C}_{29}-5 \alpha(\mathrm{H}), 14 \beta(\mathrm{H}), 17 \beta(\mathrm{H}), 24$-ethylcholestane $\beta \beta /(\alpha \alpha+\beta \beta)$;

$\mathrm{C}_{31} \alpha \beta 22 \mathrm{~S} /(22 \mathrm{R}+22 \mathrm{~S})=\mathrm{C}_{31} 17 \alpha(\mathrm{H}), 21 \beta(\mathrm{H})-30$-homohopane $22 \mathrm{~S} /(22 \mathrm{R}+22 \mathrm{~S})$.

$22 \mathrm{~S} /(22 \mathrm{~S}+22 \mathrm{R})$ have been widely used as maturity indicators $[30,31]$. In our studied samples, the ratios of $\mathrm{C}_{29}$ steranes $20 \mathrm{~S} /(20 \mathrm{~S}+20 \mathrm{R}), \mathrm{C}_{29}$ steranes $\beta \beta /(\beta \beta+\alpha \alpha)$ and $\mathrm{C}_{31}$ homohopanes $22 \mathrm{~S} /(22 \mathrm{~S}+22 \mathrm{R})$ are in the range of 0.20 $0.54,0.21-0.44$ and $0.26-0.61$, respectively (Tab. 3 ). This range indicates that the thermal maturity level of the organic matter also belongs to the immature to highly over-mature [4]. For the samples Ai-01, Ai-13, Ha-01 and Ha-02, these two parameters of $\mathrm{C}_{29}$ steranes $20 \mathrm{~S} /(20 \mathrm{~S}+20 \mathrm{R})$ and $\mathrm{C}_{29}$ steranes $\beta \beta /(\beta \beta+\alpha \alpha)$ with values of $>0.4$ and $\mathrm{C}_{31}$ homohopane $22 \mathrm{~S} /(22 \mathrm{~S}+22 \mathrm{R})$ ratios $>0.5$ reached equilibrium values indicating the thermal maturity level for coal sources [31]. However, for Wu-8, Wei-09 and Shinan-20, these parameters show values of less than 0.4 and 0.5 , respectively. This suggests an immature to early mature range [4].

\subsection{Pristane Isomerization Ratio (PIR) as a Highly Over-Mature Parameter}

The Pristane Isomerization Ratios $(\mathrm{PIR})=[6(\mathrm{R}) 10(\mathrm{R})+6(\mathrm{~S})$ $10(\mathrm{~S})] / 6(\mathrm{R}) 10(\mathrm{~S})$ obtained from the different coal samples are presented in Table 3 with the values of the molecular maturity parameters measured by $20 \mathrm{R}-20 \mathrm{~S}$ isomerization of sterane, 22R-22S isomerization of $17 \alpha(\mathrm{H}) 21 \beta(\mathrm{H})$ - homohopane, Odd/Even Predominance (OEP) and the MPI. Figure 7 and Table 3 show that the 


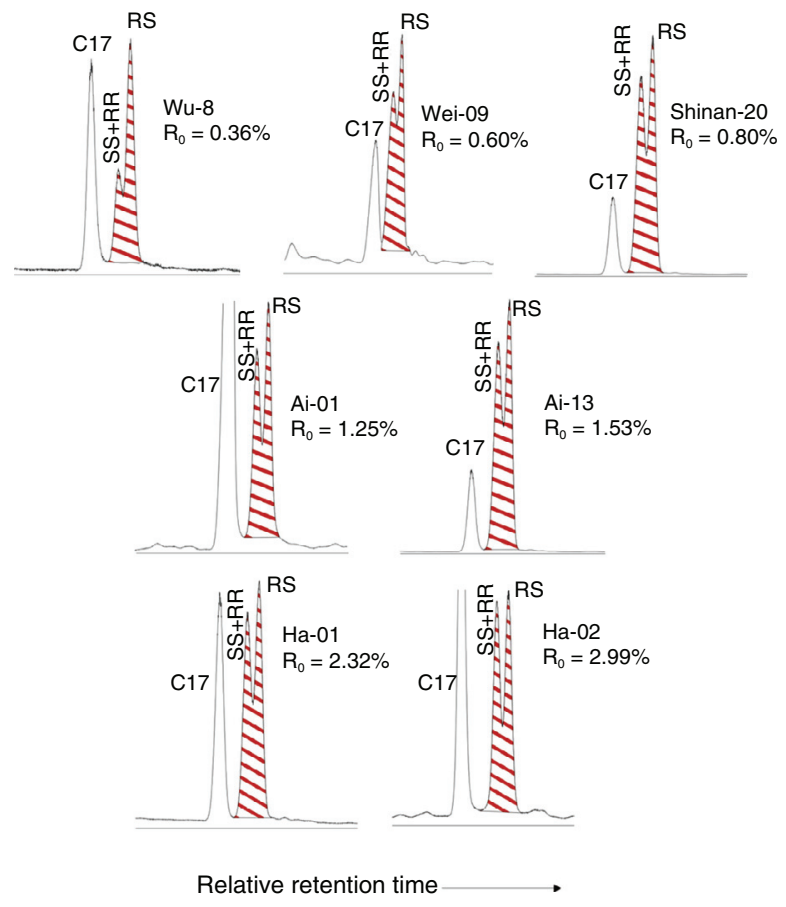

Figure 6

Example of the variations in the degree of isomerization with $R_{\mathrm{o}}$ in seven coal sample sequences in the Junggar Basin.

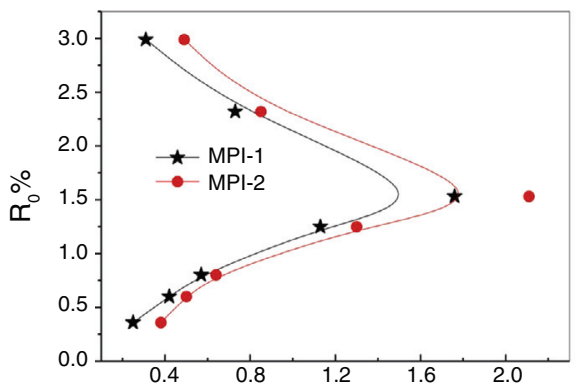

a)

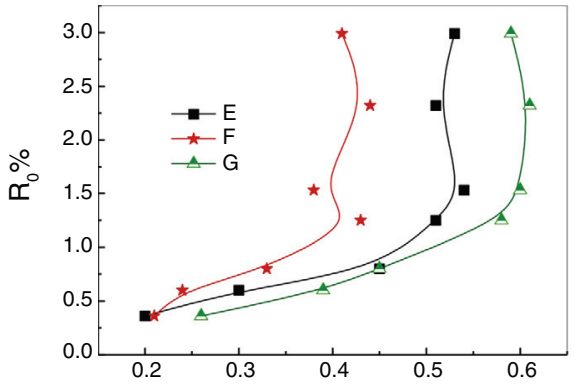

c) Sterane and hopane isomerization ratios
PIR in all the coal samples gradually increases; thermal maturity is represented by the $R_{\mathrm{o}}$ values ranging from $0.36 \%$ to $2.99 \%$. A comparison of the PIR with traditional maturity parameters (OEP, $\mathrm{C}_{31}$ homohopanes $22 \mathrm{~S} /(22 \mathrm{~S}+22 \mathrm{R}), \mathrm{C}_{29}$ steranes $20 \mathrm{~S} /(20 \mathrm{~S}+20 \mathrm{R}), \mathrm{C}_{29}$ steranes $\beta \beta /(\alpha \alpha+\beta \beta)$, MPI) was made to assess whether the PIR is directly related to maturity. The PIR increases from 0.42 to 0.97 , which is similar to an increase in the ratio of $\mathrm{C}_{31}$ homohopanes $22 \mathrm{~S} /(22 \mathrm{~S}+22 \mathrm{R}$ ) from 0.26 to 0.61 (Tab. 3). Changes are relatively small within the OEP and MPI indices, which are part of the overly mature sections $\left(R_{\mathrm{O}}>2.0 \%\right)$; however, no linear correlations between OEP and $R_{\mathrm{o}}$ or MPI and $R_{\mathrm{o}}$ have been reported (Fig. 7). In addition, the MPI shows a reversal trend at higher levels of thermal maturity (Fig. 7). All of these phenomena suggest the possibility that the OEP, saturate biomarkers $\mathrm{C}_{31}$ homohopane and sterane parameters and aromatic biomarkers MPI may have a limited application in highly mature samples. However, the PIR continues to increase with higher vitrinite reflectance values. Therefore, the PIR may be considered as a novel high-maturity index that can evaluate the maturation of coal samples in the Junggar Basin of China, and possibly other highly mature petroleum and coal samples.
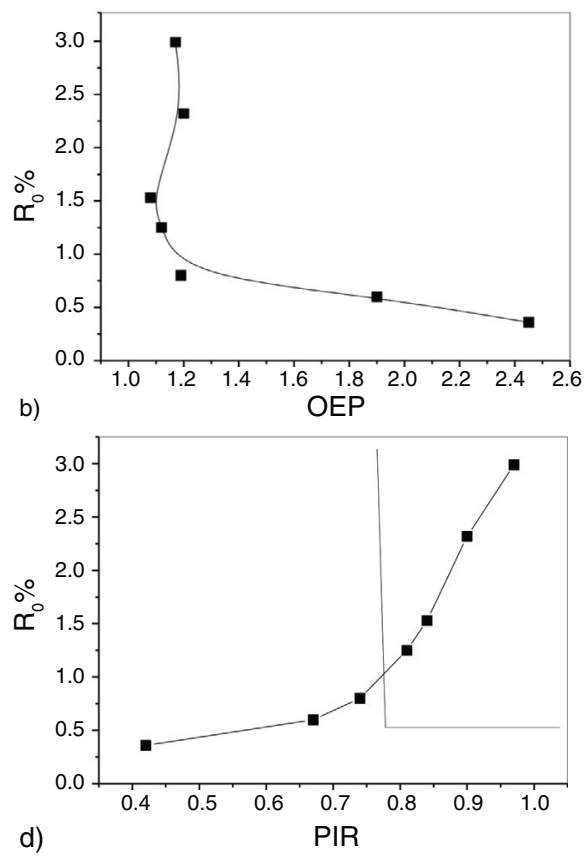

$$
\begin{aligned}
& \mathrm{MPI}-1=1.5 \times(2 \mathrm{MP}+3 \mathrm{MP}) /(\mathrm{P}+1 \mathrm{MP}+9 \mathrm{MP}) ; \mathrm{MPI}-2=(3 \times 2 \mathrm{MP}) /(\mathrm{P}+1 \mathrm{MP}+9 \mathrm{MP}) \\
& \mathrm{OEP}=\left(\mathrm{C}_{23}+6 \mathrm{C}_{25}+\mathrm{C}_{27}\right) / 4\left(\mathrm{C}_{24}+\mathrm{C}_{26}\right) ; \\
& \mathrm{E}: \mathrm{C}_{29} 20 \mathrm{~S} /(20 \mathrm{R}+20 \mathrm{~S}) ; \mathrm{F}: \mathrm{C}_{29} \beta \beta /(\alpha \alpha+\beta \beta) ; \mathrm{G}: \mathrm{C}_{31} 22 \mathrm{~S} /(22 \mathrm{R}+22 \mathrm{~S}) \\
& \mathrm{PIR}=[6(\mathrm{R}) 10(\mathrm{R})+6(\mathrm{~S}) 10(\mathrm{~S})] / 6(\mathrm{R}) 10(\mathrm{~S})
\end{aligned}
$$

Figure 7

Comparison between a) MPI, b) OEP, c) $\mathrm{C}_{29}$ sterane and $\mathrm{C}_{31}$ homohopane and d) PIR ratios versus $R_{\mathrm{o}} \%$. 
The stereoisomer distributions indicate a loss of stereospecificity of the phytol-derived $6(\mathrm{R}), 10(\mathrm{~S})$ pristane, with an increase in geological maturation. For example, the least mature geological sample Wu- 8 contains only $31 \%$ of the $6(\mathrm{R}), 10(\mathrm{R})$ and/or $6(\mathrm{~S}), 10(\mathrm{~S})$ isomers and $69 \%$ of the $6(\mathrm{R}), 10(\mathrm{~S})$ isomer. However, the over-mature sample Ha- 02 contains $49 \%$ of the $6(\mathrm{R}), 10(\mathrm{R})$ and/or $6(\mathrm{~S}), 10(\mathrm{~S})$ isomers and $51 \%$ of the $6(\mathrm{R}), 10(\mathrm{~S})$ isomer (Tab. 3). These results suggest that isomerization located at the chiral centers in acyclic isoprenoid alkanes is enhanced with thermal maturation. In the over-mature samples Ha- 01 and Ha-02 $\left(R_{\mathrm{o}}>2.0\right)$, the isomerization differences of pristane isomers are still obvious, and the relative abundances of the $6(\mathrm{R}) 10(\mathrm{R})+6(\mathrm{~S}) 10(\mathrm{~S})$ isomers show significant changes with an increase in $R_{\mathrm{O}}$. These results suggest that the PIR is an appropriate indicator of maturity for the highly mature and over-mature coal samples in the Junggar Basin.

This case study shows that the PIR increases with increasing vitrinite reflectance $\left(\% R_{\mathrm{o}}\right)$. This suggests an isomerization of the RS isomer into the RR and/or SS isomers. The ratio reached a maximum value of 0.97 in the samples examined. In a further study, it would be interesting to find a possible correlation between the vitrinite reflectance values $\left(\% R_{\mathrm{o}}\right)$ and/or the maturity and the values of the $[6(\mathrm{R}) 10(\mathrm{R})+$ $6(\mathrm{~S}) 10(\mathrm{~S})] / 6(\mathrm{R}) 10(\mathrm{~S})$ ratio.

In summary, the PIR may be of potential interest in that it can be used efficiently in measuring the maturity of highly mature coals and oils and may also be used beyond the oil window stage. However, the current work did not investigate the dependence of the PIR on kerogen type. It is necessary to further investigate and collect data of the PIR from other samples at other locations in order to improve upon this study.

\section{CONCLUSIONS}

High TOC contents, with high $\mathrm{S}_{2}$ and $\mathrm{HI}$ values, indicate that Wu-8, Wei-09, Shinan-20, Ai-01 and Ai-13 have excellent source rock potential. For Ai-01, Ai-13, Ha-01 and Ha-02, the $\mathrm{Pr} / \mathrm{Ph}$ ratios were between 0.5 and 1.0 , indicating weak oxic-anoxic environments, which are possibly favorable for reducing conditions in the lacustrine sediments and microbial activity. However, for Wu- 8 , Wei-09 and Shinan-20, the $\mathrm{Pr} / \mathrm{Ph}>3.0$ typifies terrigenous organic matter input under oxic conditions. The $\mathrm{Pr} / n-\mathrm{C}_{17}$ and $\mathrm{Ph} / n-\mathrm{C}_{18}$ values are smaller than 1.0 in $\mathrm{Ai}-01$ and $\mathrm{Ha}-02$ and this suggests that the microbial activity was less intense. In other coal samples, the $\mathrm{Ph} / n-\mathrm{C}_{18}$ values are smaller than 1.0 ; however, the $\operatorname{Pr} / n-\mathrm{C}_{17}$ values are greater than 1.0 ; this indicates that there was microbial activity, but not too strong. The $T_{\max }$ values $\left(418-531^{\circ} \mathrm{C}\right), \mathrm{C}_{29}$ sterane $20 \mathrm{~S} /(20 \mathrm{~S}+20 \mathrm{R})$ ratios $(0.20-0.54)$ and $\mathrm{C}_{31}$ homohopane $22 \mathrm{~S} /(22 \mathrm{~S}+22 \mathrm{R})$ ratios (0.26-0.61) indicate an immature to highly overmature stage of organic matter.

In addition, pristane enantiomers were completely separated and identified using GC-MS in extracts from the seven coal rocks of the Junggar Basin in China. The PIR (pristane isomerization ratio) ranges from 0.42 to 0.97 with an increase in thermal maturity evaluated from the vitrinite reflectance $\left(\% R_{\mathrm{o}}\right)$ from $0.36 \%$ to $2.99 \%$.

Pristane is an important molecular marker which can be used for petroleum geochemical investigations. The PIR could be used in combination with sterane and hopane maturity parameters, as well as a MPI, to measure hydrocarbon maturity from the immature $\left(R_{\mathrm{o}}<0.6 \%\right)$, mature $\left(R_{\mathrm{o}}, 0.6-1.3 \%\right)$ and past mature $\left(R_{\mathrm{o}}, 1.3-2.0 \%\right)$ to overmature stages $\left(R_{\mathrm{o}}>2.0 \%\right)$.

An increase in the pristane $[6(\mathrm{R}) 10(\mathrm{R})+6(\mathrm{~S}) 10(\mathrm{~S})] /$ $6(\mathrm{R}) 10(\mathrm{~S})$ maturity parameter resulted from the relatively greater rate of generation of the 6(R)10(R) and 6(S)10(S) isomers, combined with the earlier decline in concentration (by isomerization) of the $6(\mathrm{R}) 10(\mathrm{~S})$ component. The isomerization at the chiral centers in pristane is obvious as thermal maturation increases, and the PIR shows a significant increase at high maturity, due to the greater relative thermal stability of the $6(\mathrm{R}) 10(\mathrm{R})$ and $6(\mathrm{~S}) 10(\mathrm{~S})$ isomers.

The PIR can be used to measure the maturity of source rocks even at highly mature stages in the elevated vitrinite reflectance scale of maturity $\left(\% R_{\mathrm{o}}\right)$ of $2.0-3.0 \%$.

\section{ACKNOWLEDGMENTS}

We thank Professors Guodong Zheng for discussing the paper, and Jincai Tuo and Ping Shen for providing valuable samples. Financial support from the Chinese Academic of Sciences Key Project (No. XDB03020405), the Major State Basic Research Development Program of China (No. 2012CB214701), the National Science Foundation (41272147, 41172169, 41072107, 41202093), the Key Laboratory of Tectonics and Petroleum Resources, Ministry of Education Open-end Foundation (TPR-2012-18) and Western Light Joint Scholars Project.

\section{REFERENCES}

1 van Graas G.W. (1990) Biomarker maturity parameters for high maturities: Calibration of the working range up to the oil/condensate threshold, Organic Geochemistry 16, 1025-1032.

2 Li J.G., Paul P., Cui M.Z. (2000) Methyl diamantane index (MDI) as a maturity parameter for Lower Palaeozoic carbonate rocks at high maturity and overmaturity, Organic Geochemistry 31, 267-272. 
3 Brocks J.J., Buick R., Logan G.A., Summons R.E. (2003) Composition and syngeneity of molecular fossils from the 2.78 to 2.45 billion-year-old Mount Bruce Supergroup, Pilbara Craton, Western Australia, Geochimica et Cosmochimica Acta 67, 4289-4319.

4 Peters K.E., Walters C.C., Moldowan J.M. (2005) The Biomarker Guide, 2nd edn., Cambridge University Press, Cambridge, U.K., p. 1155.

5 Hackley P.C., Ryder R.T., Trippi M.H., Alimi H. (2013) Thermal maturity of northern Appalachian Basin Devonian shales: Insights from sterane and terpane biomarkers, Fuel 106, 455-462.

6 Radke M., Welte D.H., Willsch H. (1986) Maturity parameters based on aromatic hydrocarbons: Influence of the organic matter type, Organic Geochemistry 10, 51-63.

7 Chiaberge S., Fiorani T., Cesti P. (2011) Methyldibenzothiophene isomer ratio in crude oils: Gas chromatography tandem mass spectrometry analysis, Fuel Processing Technology 92, 2196-2201.

8 Chen J.H., Fu J.M., Sheng G.Y., Liu D.H., Zhang J.J. (1996) Diamondoid hydrocarbon ratios: novel maturity indices for highly mature crude oils, Organic Geochemistry 25, 179-190.

9 Li M.J., Zhong N.N., Shi S.B., Zhu L., Tang Y.J. (2013) The origin of trimethyldibenzothio-phenes and their application as maturity indicators in sediments from the Liaohe Basin, East China, Fuel 103, 299-307.

10 Wolf F.R., Nemethy E.K., Blanding J.H., Bassham J.A., Bassham J.A. (1985) Biosynthesis of unusual acyclic isoprenoids in the Alga Botryococcus braunii, Phytochemistry 24, 733-737.

11 Tissot B.P., Welte B.H. (1984) Petroleum formation and occurrence, 2 nd edn., Springer, Berlin.

12 Volkman J.K., Maxwell J.R. (1986) Acyclic isoprenoids as biological markers, in Biological Markers in the Sedimentary Record, R.B. Johns (ed.), Elsevier, Amsterdam, pp. 1-46.

13 Rontani J.F., Nassiry M., Michotey V., Guasco S., Bonin P. (2010) Formation of pristane from a-tocopherol under simulated anoxic sedimentary conditions: A combination of biotic and abiotic degradative processes, Geochimica et Cosmochimica Acta 74, 252-263.

14 Patience R.L., Rowland S.J., Maxwell J.R. (1978) The effect of maturation on the configuration of pristane in sediments and petroleum, Geochimica et Cosmochimica Acta 42, 1871-1875.

15 Patience R.L., Yon D.A., Ryback G., Maxwell J.R. (1980) Acyclic isoprenoid alkanes and geochemical maturation, Physics and Chemistry of the Earth 12, 287-293.

16 Kuang L.C., Lu H.T., Wang X.L., Yang D.S., Sun Z.C., Ling L.S. (2010) Exploration of volcanic gas reservoirs and discovery of the Kelameili gas field in the Junggar Basin, Natural Gas Industry 30, 1-6. (in Chinese).

17 Zhou J.B., Zhuang X.G., Alastuey A., Querol X., Li J.H. (2010) Geochemistry and mineralogy of coal in the recently explored Zhundong large coal field in the Junggar basin, Xinjiang province, China, International Journal of Coal Geology 82, 51-67.
18 Coleman R.G. (1989) Continental growth of northwest China, Tectonics 8, 621-635.

19 Chen X., Lu H.F., Shu L.S., Wang H.M., Zhang G.Q. (2002) Study on tectonic evolution of Junggar Basin, Geological Journal of China Universities 8, 257-267.

20 Wu K.Y., Zha M., Wang X.L., Qu J.X., Chen X. (2005) Further researches on the tectonic evolution and dynamic setting of the Junggar Basin, Acta Geological Sinica 26, 217-222. (in Chinese with English abstract).

21 Qi J.F., Chen S.P., Yang Q., Yu F.S. (2008) Characteristics of tectonic deformation within transitional belt between the Junggar Basin and the northern Tianshan Mountain, Oil \& Gas Geology 29, 252-260. (in Chinese with English abstract).

22 Qiu N.S., Zhang Z.H., Xu E.S. (2008) Geothermal regime and Jurassic source rock maturity of the Junggar basin, northwest China, Journal of Asian Earth Sciences 464-478.

23 Wang Z., Ye L., Wei B. (2006) Coal formation at a major coal bed in Xishanyao Group of the Zhuannan coal field, Xinjiang Geology 24, 157-160. (in Chinese with English abstract).

24 Duan Y., Wu B.X., He J.X., Sun T. (2011) Characterization of gases and solid residues from closed system pyrolysis of peat and coals at two heating rates, Fuel 90, 974-979.

25 Goossens H., de Leeuw J.W., Schenck P.A. (1984) Tocopherols as likely precursors of pristane in ancient sediments and crude oils, Nature 312, 440-442.

26 de las Heras X., Grimalt J.O., Albaiges J., Julia R., Anadon P. (1989) Origin and diagenesis of the organic matter in Miocene freshwater lacustrine phosphates (Cerdanya Basin, Eastern Pyrenees), Organic Geochemistry 14, 667-677.

27 Rieley G., Collier R.J., Jones D.M., Eglinton G. (1991) The biogeochemistry of Ellesmere Lake, UK-I: Source correlation of leaf wax inputs to the sedimentary lipid record, Organic Geochemistry 17, 901-912.

28 Brooks J.D., Gould K., Smith J. (1969) Isoprenoid hydrocarbons in coal and petroleum, Nature 222, 257-259.

29 Didyk B.M., Simoneit B.R.T., Brassell S.C., Eglinton G. (1978) Organic geochemical indicators of paleoenvironmental conditions of sedimentation, Nature 272, 216-222.

30 Böcker J., Littke R., Hartkopf-Fröder C., Jasper K., Schwarzbauer J. (2013) Organic geochemistry of Duckmantian (Pennsylvanian) coals from the Ruhr Basin, western Germany, International Journal of Coal Geology 107, 112-126.

31 Peters K.E., Fraser T.H., Amris W., Rustanto B., Hermanto E. (1999) Geochemistry of crude oils from eastern Indonesia, American Association of Petroleum Geologists Bulletin 83, 1927-1942. Manuscript submitted in August 2014
Manuscript accepted in June 2015
Published online in October 2015

Cite this article as: Y. Wu, Y. Xia, Y. Wang, T. Lei, Y. Liu, Y. Liu, X. Hou and Y. Wang (2016). The Geochemical Characteristics of Coals from the Junggar Basin in Northwest China and the Relation of the Configuration of Pristane with Maturity in Highly Mature and Over-Mature Samples, Oil Gas Sci. Technol 71, 35. 